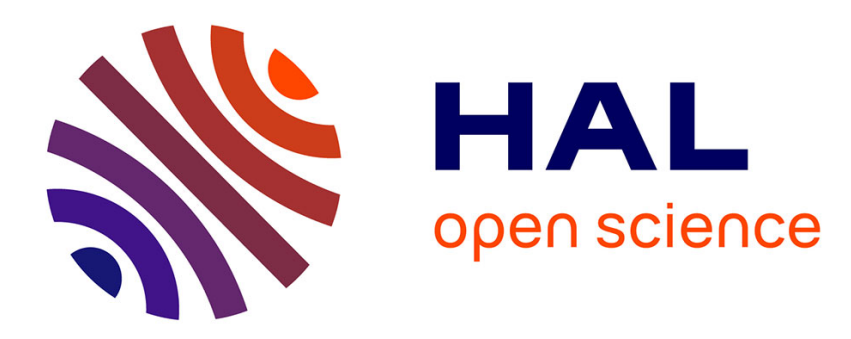

\title{
Spall behaviour of the low alloyed high strength steel
}

\author{
J. Buchar, J. Krejcí
}

\section{To cite this version:}

J. Buchar, J. Krejcí. Spall behaviour of the low alloyed high strength steel. Journal de Physique IV Proceedings, 1994, 04 (C8), pp.C8-713-C8-716. 10.1051/jp4:19948109 . jpa-00253350

\section{HAL Id: jpa-00253350 https://hal.science/jpa-00253350}

Submitted on 1 Jan 1994

HAL is a multi-disciplinary open access archive for the deposit and dissemination of scientific research documents, whether they are published or not. The documents may come from teaching and research institutions in France or abroad, or from public or private research centers.
L'archive ouverte pluridisciplinaire HAL, est destinée au dépôt et à la diffusion de documents scientifiques de niveau recherche, publiés ou non, émanant des établissements d'enseignement et de recherche français ou étrangers, des laboratoires publics ou privés. 


\title{
Spall behaviour of the low alloyed high strength steel
}

\author{
J. Buchar and J. Krejcí* \\ Department of Physics, University of Agriculture, Brno, Czech Republic \\ * Institute of Physics of Materials, Czech Ac. Sci., Brno, Czech Republic
}

\begin{abstract}
Des theories basées sur I` energie de rupture d`ecaillage sont examinées. L`influence de la structure est etudiee. La transition fracture est examinée.
\end{abstract}

The spall behaviour of low alloyed high strength steel was studied. Nine different microstructures of this steel were prepared. The experimentally found dependence of spall strength, $\sigma_{\mathrm{C}}$, on the strain rate, $\dot{\varepsilon}$, exhibited features suggesting a transition in the spall fracture mode. The results were interpreted in terms of an energy-based theory of spall.

\section{INTRODUCTION}

Spallation (spall-fracture) is a kind of fracture that occurs as a planar separation of the dynamically loaded body along the direction parallel to the incident and reflected plane wave fronts caused by the dynamic loads[1].

The evaluation of spall in a body subjected to the dynamic loading involves cooperative nucleation, growth and coalescence processes that depend on both the pre-existing and the evolving microstructure of the spalling body. The exact evaluation of the spall-fracture with respect to the above mentioned factors is very complicated[2-4]. For this reason, approaches to the spall description are used. One of them is the energy-based spall theory[5-7]. This theory uses a balance of the driving energy in the stress wave loading and some continuum measure of fracture dissipation such as fracture toughness, surface tension etc.

The aim of this paper consists in futher verification of the energy-based spall theory.

\section{EXPERIMENTAL DETAILS.}

For experiments the ultrahigh strength low alloyed steel $(0.75 \mathrm{C}, 1.68 \mathrm{Si}, 1.8 \mathrm{Mn}, 0.014$ $\mathrm{P}, 0.005 \mathrm{~S}, 1.03 \mathrm{Cr}, 0.14 \mathrm{Ni}, 0.08 \mathrm{Cu}$-in wt. \%) was chosen. By use of different heat treatment several different microstructures were prepared. Their mechanical and fracture properties are given in Table 1.

The spall fracture behavior of this steel was studied with experimental method described e.g. in $[8,9]$. Specimen discs $100 \mathrm{~mm}$ in diameter were machined to thickness $20 \mathrm{~mm}$. The specimens were subjected to shock loading produced by the detonation of the explosive charge This method enable us to determine the course of the loading stress (pressure), $\mathrm{p}(\mathrm{t})$, as well as the time history of the free surface velocity, $v(t)$. The knowledge of $p(t)$ and $v(t)$ is sufficient to determine the spall strength, $\sigma_{\mathcal{C}}$, and the strain rate, $\varepsilon$, in the spall plane. 


\section{RESULTS AND DISCUSSION}

In Fig. 1 the values of $\sigma_{c}$ and $\dot{\varepsilon}$ for different microstructures of the tested steel are plotted. The logarithm of the spall strength increases linearly with the logarithm of the strain rate up to some value, $\dot{\varepsilon}_{\mathfrak{c}}$, and then remains nearly constant. According to the energy-based spall theory the increase of $\sigma_{\mathrm{c}}$ with $\dot{\varepsilon}$ can be expressed as

$$
\left.\sigma_{\mathrm{c}=\left(3 \rho \varepsilon^{\prime} \mathrm{c}_{\mathrm{o}}\right.} \mathrm{K}_{\mathrm{c}}{ }^{2}\right)^{(1 / 3)}
$$

where $\rho$ is the material density, $c_{o}=(B / \rho)^{1 / 2}, B$ is the elastic bulk modulus of the material and $K_{c}$ is the fracture toughness. Eq.(1) is valid for solids which fail through the growth and coalescence of cracks.

If the material fails through the growth and linking up of holes, the energy-based theory predicts that the spall strength $\sigma_{\mathrm{C}}$ is given by

$$
\sigma_{\mathrm{c}}=\left(2 \mathrm{Yc}_{\mathrm{o}}{ }^{2} \rho \varepsilon_{\mathrm{v}}\right)^{1 / 2}
$$

where $Y$ is the flow stress which is assumed to completely characterize the local plasticity during spall failure., $\varepsilon_{\mathrm{V}}$ is the critical void fraction, after which void coalescence and fast loss of tensile loadcarrying capability ensue. Some studies, see e.g. [10], indicate that $\varepsilon_{\mathrm{V}}$ is about 0.15 , independently of the kind of material.

Table.1Tensile and fracture properties of the tested steel.

\begin{tabular}{||l|l|l|l|l|l||l||}
\hline Specimen & \multicolumn{2}{|c|}{ Heat treatment } & $\begin{array}{l}\text { Yield } \\
\text { strength }\end{array}$ & $\begin{array}{l}\text { Ultimate } \\
\text { tensile } \\
\text { strength }\end{array}$ & Hardness & $\begin{array}{l}\text { Fracture } \\
\text { toughness }\end{array}$ \\
\hline CODE & $\begin{array}{l}\text { Quenching } \\
\text { temperature } \\
\left({ }^{\circ} \mathrm{C}\right)\end{array}$ & $\begin{array}{l}\text { Tempering } \\
\text { temperature } \\
\left({ }^{\circ} \mathrm{C}\right)\end{array}$ & $(\mathrm{MPa})$ & $(\mathrm{MPa})$ & $(\mathrm{HV} 10)$ & $\left(\mathrm{MPam}^{1 / 2}\right)$ \\
\hline $\mathrm{R}$ & 1100 & 180 & 1390 & 1818 & 600 & 69 \\
\hline $\mathrm{C}$ & 840 & 180 & 1530 & 1978 & 550 & 52 \\
\hline $\mathrm{D}$ & & 250 & 1470 & 1732 & 480 & 49 \\
\hline $\mathrm{E}$ & & 320 & 1440 & 1620 & 477 & 52 \\
\hline $\mathrm{F}$ & & 400 & 1401 & 1518 & 439 & 72 \\
\hline $\mathrm{G}$ & & 500 & 1220 & 1256 & 389 & 95 \\
\hline $\mathrm{H}$ & & 600 & 1070 & 1104 & 345 & 124 \\
\hline $\mathrm{K}$ & & 650 & 890 & 929 & 287 & 140 \\
\hline $\mathrm{L}$ & & 700 & 750 & 867 & 270 & 168 \\
\hline
\end{tabular}

It may be seen that the data plotted in Fig.1 can be fitted by Eq(1) or Eq(2), depending on the strain rate regime. This results is rather suprising because the used values of fracture toughness and flow stress were determined at very low strain rates, about $10^{-4} \mathrm{~s}^{-1}$.It is well known that the fracture toughness is mostly a decreasing function of the strain rate. At the same time the flow stress usually increases with the strain rate, e.g. 12

The dependence of spall strength vs. strain rate curves such as those displayed in Fig. 1 is interpreted as an evidence of a brittle- to-ductile transition in the fracture mode[6]. this hypothesis was supported in the present study by the observation of fracture surfaces. These observations revealed that the fracture was ductile for all strain rates. The lower rate experiments exhibited evidence of the mature 


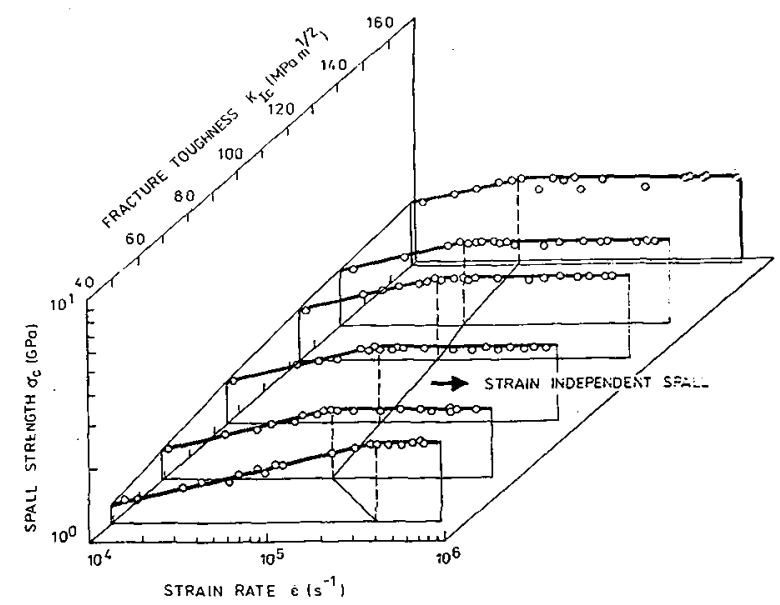

Fig.1 The influence of the strain rate on the spall strength.

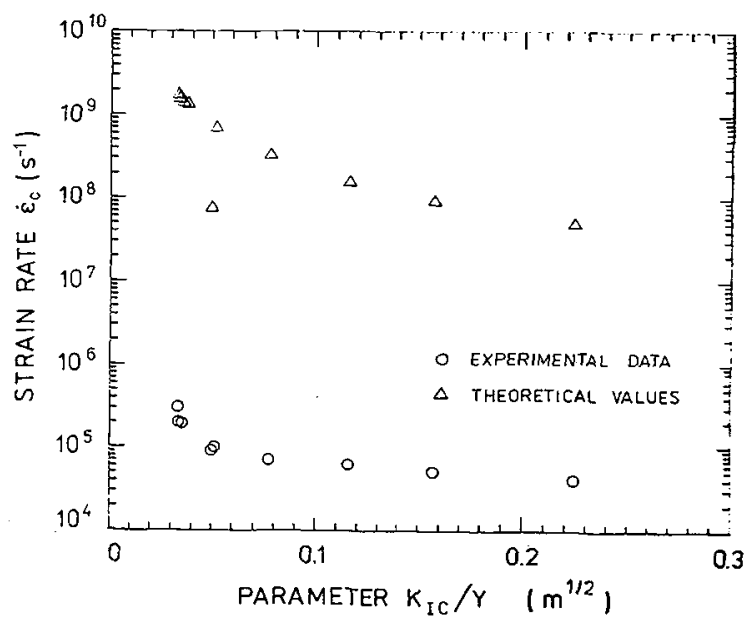

Fig.2 The dependence of the critical strain rate on the $\mathrm{K}_{\mathrm{IC}} / \mathrm{Y}$ parameter. 
crack formation prior to coalescence failure. The micrographs of the higher rate spalled specimens suggested that the failure occured through hole linkup without mature formation.

This spall mechanism transition was interpreted in [6] using a mechanistic theory of ductile fracture. This theory deals with the plastic zone at the tip of a ductile crack where local plasticity leads to ductile hole growth.The characteristic length of this process zone is given as

$$
\mathrm{x}_{\mathrm{pz}}=(\pi / 72) *\left(\mathrm{~K}_{\mathrm{c}} / \mathrm{Y}\right)^{2}
$$

The strain rate which corresponds to the fracture mode transition is the rate at which the spall horizon (characteristic fracture spacing) approaches that of the process zone length. This strain rate can be easily evaluated by the equating the spall strengths in Eqs(1) and (2), i.e.,

$$
\dot{\varepsilon}_{\mathrm{c}}=(2 / 3)^{*}\left(\mathrm{c}_{0} / \mathrm{K}_{\mathrm{c}}\right)^{2 *\left(2 * \mathrm{Y}^{3} \rho \varepsilon_{\mathrm{v}}\right)^{3 / 2}}
$$

Fig.2 shows the dependence of $\varepsilon_{c}$ on the parametr $K_{c} / Y$ is plotted (The fracture toughness $K_{c}$ is denoted as $\mathrm{K}_{\mathrm{IC}}$ ) where $\mathrm{Y}$ is taken as an average of the yield strength and ultimate tensile strength,i.e., $\mathrm{Y}=\left(\mathrm{R}_{\mathrm{p} 0.2}+\mathrm{R}_{\mathrm{m}}\right) / 2$.

The theoretical values obtained for $\dot{\varepsilon}_{\mathrm{c}}$ from $\mathrm{Eq}(4)$ exhibit a form of dependence upon $\mathrm{K}_{\mathrm{c}} / \mathrm{Y}$ similar to that observed experimentally. However, the magnitudes of these theoretical values are substantially higher than the experimental results. A neglected dependence of $K_{c}$ and $Y$ upon strain rate is the suggested explanation.

\section{CONCLUDING REMARKS.}

The experimental data obtained in the present work show that the energy-based spall theory gives a a a reasonable view of the spall behaviour of the tested steel. There are several points which require futher study :

-The dependence of the spall strength on the strain rate given by Eqs.(1) and (2) must be extended in order to include the influence of the strain rate on the flow stress and fracture toughness.

-The quantitative description of the transition in spall mechanism should include some models of the defect origin.

\section{REFERENCES}

1.Davieson L. and Graham R.A.:Phys.Rept.55(1979)257.

2.Nellis W.J.,Seaman L. and Graham R.A.:Shock waves in condensed matter-1981.Am.Inst.Phys.,New York 1982.

3.Meyers M.A. and Aimone T.C.:Progress in Mat. Sci.28(1983)1.

4.Curran D.R.,Seaman L. and Shockey D.A.:Phys.Rept.147(1987)254.

5.Grady D.E. and Kipp M.E.:Mech.Mat.4(1985)311.

6.Grady D.E.:Journal de Physique49(1988)175.

7.Engelman R.,Rivier N and Jaeger Z.:Phil.Mag.B56(1987)751.

8.Buchar J.:Acta Technica(1988)545.

9.Buchar J.,Rolc S. and Pechacek J.:In:Shock waves loading and high strain rate phenomena(M.A.Meyers et al.,Eds.), Marcel Dekker, New York 1992.

10.Tveergard V. and Needleman A.:Acta metall.32(1984)157.

11Dugdale D.S.: J.Mech.Phys.Solids8(1960)100.

12.J.Buchar,Z.Bílek,F.Dušek: Behaviour of metals under extremaly high rates of strain.

Trans.Tech.Publ. Switzerland-U.K.-U.S.A. 1986. 